\title{
The role of information competencies and skills in learning to abstract
}

\author{
Maria Pinto ${ }^{1}$ \\ University of Granada
}

Anne-Vinciane Doucet; Andrés Fernández-Ramos

University of Granada

\begin{abstract}
The ability to abstract information is a basic competency in today's knowledge society, characterised by the mass diffusion of information and the need to manage and access it effectively. Yet abstracting is not an easy task, and requires a specific learning process. This paper examines the process of abstracting information from the perspective of competencies and skills based learning. The competencies and skills necessary in this process are identified by analysing in detail the various stages and processes involved in writing an abstract. The general skills required for the whole process, as well as the specific skills for each stage, are determined. Guidelines and recommendations are put forward to facilitate the learning of these skills in the context of abstracting.
\end{abstract}

Keywords: abstracting; skills;informational competencies

\section{Introduction}

The environment and philosophy of educational processes are changing, particularly in the area of higher education, where learning based on the student's competencies and skills is becoming increasingly important. These competencies and skills centre on analysis and synthesis, the organisation and management of information flows and the access to and use of information in decision making. The ultimate aim of these competencies is to enable the student to work autonomously, to use the appropriate tools interactively and to work in groups effectively. The link between knowledge and know-how should be maintained at all times. Theory must also be learned, although theory on its own is meaningless if it is not put into practice [1]. There is a distinct difference between memory-based learning, in which new knowledge is not incorporated into the reader's cognitive structure, and meaningful learning whereby learners consciously choose to integrate new knowledge into their previously processed knowledge. In this context of a changing electronic media environment in which information

${ }^{1}$ Correspondence to: MariaPinto, Campus de la Cartuje, s/n 18071 Granada, Spain, mpinto@ugr.es 
is ever-increasing, complex and in most cases, unstructured and disperse, information literacy provides the most appropriate overall frameworks.

\subsection{Information literacy}

Information literacy entails the learning of the skills, competencies, knowledge and values to access, use and communicate information in any of its forms, in order to produce competent students and professionals trained in the routines of identifying, evaluating and recording information sources appropriately and with the knowledge to process and produce their own information. This is a continuous process and an intelligent commitment to lifelong learning on the part of education systems. Students should be aware of the goals for which they are going to use the information, and the context in which it is to be used (for personal use, acquiring information, generating knowledge, and so on). They should know how to use available technologies to organise and store information, be able to assimilate the essential content of documents, and understand their key concepts and how they are related in order to synthesise and represent the essential information properly. In our electronic world, students must be instructed and prepared to exploit, filter and use all formats of information.

The idea of information literacy, emerging with the advent of information technologies in the early 1970s, has grown, taken shape and strengthened to become recognised as the critical literacy for the twenty-first century. Sometimes interpreted as one of a number of literacies, information literacy is also described as the overarching literacy essential for twenty-first century living. Today, information literacy is inextricably associated with information practices and critical thinking in the information and communication technology environment [2]. The recent emergent importance of information literacy to the learning process is reflected in numerous publications [3], [4], [5], [6].

Webber and Johnston [7] define information literacy as the adoption of appropriate information behaviour to identify, through whatever channel or medium, information well fitted to information needs, leading to wise and ethical use of information in society. The following table (table 1) presents the set of competencies and skills in four of the most important information literacy standards developed by a number of library associations: the Association of College and Research Libraries - American Library Association; the American Association of School Libraries/ Association for Educational Communications and Technology; the Society of College, National and University Libraries (UK); and the Council of Australian University Librarians / Australian and New Zealand Institute for Information Literacy:

\begin{tabular}{|c|c|c|c|c|}
\hline & $\begin{array}{l}\text { ACRL } \\
(2000)[8]\end{array}$ & $\begin{array}{l}\text { AASL \& AECT (1998) } \\
\text { [9] }\end{array}$ & SCONUL (1999) [10] & $\begin{array}{l}\text { CAUL \& ANZIIL } \\
(2004)[11]\end{array}$ \\
\hline $\begin{array}{l}\text { Identification } \\
\text { of information } \\
\text { needs }\end{array}$ & $\begin{array}{l}\text { 1. The information } \\
\text { literate student } \\
\text { defines and } \\
\text { articulates the need } \\
\text { for information. }\end{array}$ & $\begin{array}{l}\text { 4. The student who is an } \\
\text { independent learner is } \\
\text { information literate and } \\
\text { pursues information } \\
\text { related to personal } \\
\text { interests. }\end{array}$ & $\begin{array}{l}\text { 1. The ability } \text { to } \\
\text { recognise a need for } \\
\text { information }\end{array}$ & $\begin{array}{l}\text { 1. The information } \\
\text { literate person } \\
\text { recognises the need for } \\
\text { information and } \\
\text { determines the nature } \\
\text { and extent of the } \\
\text { information needed }\end{array}$ \\
\hline $\begin{array}{l}\text { Access to } \\
\text { information }\end{array}$ & $\begin{array}{l}\text { 2. The information } \\
\text { literate student } \\
\text { accesses needed } \\
\text { information } \\
\text { effectively and } \\
\text { efficiently. }\end{array}$ & $\begin{array}{l}\text { 1. The student who is } \\
\text { information literate } \\
\text { accesses information } \\
\text { efficiently and effectively. } \\
\text { 6. The student who is an } \\
\text { independent learner is } \\
\text { information literate and } \\
\text { strives for excellence in } \\
\text { information seeking and } \\
\text { knowledge generation. }\end{array}$ & $\begin{array}{l}\text { 2. The ability to } \\
\text { distinguish ways in } \\
\text { which the information } \\
\text { 'gap' may be addressed } \\
\text { 3. The ability to } \\
\text { construct strategies for } \\
\text { locating information } \\
\text { 4. The ability to locate } \\
\text { and access information }\end{array}$ & $\begin{array}{lr}2 . & \text { The information } \\
\text { literate person finds } \\
\text { needed information } \\
\text { effectively } \\
\text { efficiently }\end{array}$ \\
\hline $\begin{array}{l}\text { Evaluation of } \\
\text { information }\end{array}$ & $\begin{array}{l}\text { 3. The information } \\
\text { literate student } \\
\text { evaluates information }\end{array}$ & $\begin{array}{l}\text { 2. The student who is } \\
\text { information literate } \\
\text { evaluates information }\end{array}$ & $\begin{array}{l}\text { 5. The ability to } \\
\text { compare and evaluate } \\
\text { information obtained }\end{array}$ & $\begin{array}{lr}\text { 3. The } & \text { information } \\
\text { literate } & \text { person } \\
\text { critically } & \text { evaluates }\end{array}$ \\
\hline
\end{tabular}


Maria Pinto, Anne-Vinciane Doucet, Andrés Fernández-Ramos

\begin{tabular}{|c|c|c|c|c|}
\hline & $\begin{array}{l}\text { and its } r \text { sources } \\
\text { critically } r \text { and } \\
\text { incorporates selected } \\
\text { information into his } \\
\text { or her knowledge } \\
\text { base and value } \\
\text { system. }\end{array}$ & $\begin{array}{l}\text { critically and competently. } \\
5 \text {. The student who is an } \\
\text { independent learner is } \\
\text { information literate and } \\
\text { appreciates literature and } \\
\text { other creative expressions } \\
\text { of information }\end{array}$ & from different sources. & $\begin{array}{l}\text { information and the } \\
\text { information } \\
\text { process }\end{array}$ \\
\hline $\begin{array}{l}\text { Efficient } \\
\text { management } \\
\text { and use of } \\
\text { information }\end{array}$ & $\begin{array}{l}\text { 4. The information } \\
\text { literate student, } \\
\text { individually or as a } \\
\text { member of a group, } \\
\text { uses information } \\
\text { effectively to } \\
\text { accomplish a specific } \\
\text { purpose. }\end{array}$ & $\begin{array}{l}\text { 3. The student who is } \\
\text { information literate uses } \\
\text { information accurately and } \\
\text { creatively. }\end{array}$ & $\begin{array}{l}\text { 6. The ability to } \\
\text { organise, apply and } \\
\text { communicate } \\
\text { information to others in } \\
\text { ways appropriate to the } \\
\text { situation } \\
7 \text { The ability to } \\
\text { synthesise and build } \\
\text { upon existing } \\
\text { information, to the } \\
\text { contributing to } \\
\text { creation of new } \\
\text { knowledge }\end{array}$ & $\begin{array}{lr}4 . \text { The information } \\
\text { literate person } \\
\text { manages information } \\
\text { collected or generated. } \\
5 . \text { The information } \\
\text { literate person applies } \\
\text { prior and new } \\
\text { information r to } \\
\text { construct new concepts } \\
\text { or creater new } \\
\text { understandings }\end{array}$ \\
\hline $\begin{array}{l}\text { Ethical and } \\
\text { contextualised } \\
\text { use of } \\
\text { information }\end{array}$ & $\begin{array}{l}\text { 5. The information } \\
\text { literate student } \\
\text { understands many of } \\
\text { the economic, legal, } \\
\text { and social issues } \\
\text { surrounding the use } \\
\text { of information and } \\
\text { accesses and uses } \\
\text { information ethically } \\
\text { and legally. }\end{array}$ & $\begin{array}{l}\text { 7. The student who } \\
\text { contributes positively to } \\
\text { the learning community } \\
\text { and to society is } \\
\text { information literate and } \\
\text { recognizes the importance } \\
\text { of information to a } \\
\text { democratic society. } \\
\text { 8. The student who } \\
\text { contributes positively to } \\
\text { the learning community } \\
\text { and to society is } \\
\text { information literate and } \\
\text { practices ethical behavior } \\
\text { in regard to information } \\
\text { and information } \\
\text { technology. } \\
\text { 9. The student who } \\
\text { contributes positively to } \\
\text { the } \\
\text { learning community and } \\
\text { to society is information } \\
\text { literate } \\
\text { and participates } \\
\text { effectively in groups to } \\
\text { pursue and generate } \\
\text { information. }\end{array}$ & - & $\begin{array}{l}\text { 6. The information } \\
\text { literate person uses } \\
\text { information with } \\
\text { understanding and } \\
\text { acknowledges cultural, } \\
\text { ethical, economic, } \\
\text { legal, and social issues } \\
\text { surrounding the use of } \\
\text { information }\end{array}$ \\
\hline
\end{tabular}

Table 1. Library association standards

We focus specifically on the third and fifth competencies established by the ACRL, since they are the most closely linked to the process of analysis, synthesis and abstracting information, both for the learning process and in professional life. The information literate student should be capable of abstracting the main ideas from any document, by selecting, generalising and integrating the relevant information, and putting it into his or her own words to construct new knowledge, while remaining faithful to the original information. To substantiate this claim, below we transcribe the text from some sections taken from the two standards (table 2): 


\begin{tabular}{|c|c|}
\hline \multirow{3}{*}{$\begin{array}{l}\text { A person skilled in accessing and using information is } \\
\text { able to abstract the main ideas of a document and extract } \\
\text { the information. To that end he or she: }\end{array}$} & Reads the text and selects the main ideas \\
\hline & $\begin{array}{l}\text { Writes down the main concepts in his or her own words, } \\
\text { and faithfully selects the data }\end{array}$ \\
\hline & $\begin{array}{l}\text { Accurately gathers the material that will later be cited } \\
\text { verbatim }\end{array}$ \\
\hline \multirow{2}{*}{$\begin{array}{l}\text { A person skilled in accessing and using information } \\
\text { synthesises the main ideas with the aim of generating } \\
\text { concepts and a new product. He or she: }\end{array}$} & $\begin{array}{l}\text { Organises the content in such a way that it supports the } \\
\text { purposes and format of the product }\end{array}$ \\
\hline & $\begin{array}{l}\text { Integrates the new information into the above, including } \\
\text { words and ideas, in such a way that it supports the } \\
\text { function of the product. }\end{array}$ \\
\hline $\begin{array}{l}\text { A person skilled in accessing and using information is } \\
\text { able to synthesise the main ideas to construct new } \\
\text { concepts. He or she: }\end{array}$ & $\begin{array}{l}\text { Recognises the interrelationships between concepts and } \\
\text { assembles them in new, potentially useful, primary } \\
\text { statements supported by corresponding evidence. }\end{array}$ \\
\hline \multirow[t]{3}{*}{$\begin{array}{l}\text { A person skilled in accessing and using information is } \\
\text { able to communicate the product to others effectively. He } \\
\text { or she: }\end{array}$} & $\begin{array}{l}\text { Chooses the means and format of communication that } \\
\text { best suits the intention of the product and the target } \\
\text { audience. }\end{array}$ \\
\hline & $\begin{array}{l}\text { Uses suitable technological applications to generate the } \\
\text { product. }\end{array}$ \\
\hline & $\begin{array}{l}\text { Clearly communicates in a style suited to the purposes of } \\
\text { the target audience. }\end{array}$ \\
\hline
\end{tabular}

Table 2. On the abstracting competency. Extract from Information Literacy standards three and five. ALA, 2000

\subsection{Abstracting}

In light of these standards it therefore seems patently clear that the abstract plays a fundamental role in the training of university students. This applies not only to documentation students, for whom training in document abstracting techniques is clearly intrinsic to their studies, but to all students; the ever-increasing volume of information at their fingertips means that they must be able to manage it correctly if they are to use it well. Nowadays, the dramatic growth in the number of documents and the time pressures we all suffer have made abstracting more important than ever. Rather than reducing the need for abstracts, technological advances have had precisely the opposite effect: the development of the Internet has increased the need for different ways of filtering information, of which the abstract is the key resource [12]. Today readers have to skim and search far more than they had to do in the past and the abstract is continually evolving as a gateway into the research literature [13].

Knowing how to abstract is an increasingly valuable asset for any student, teacher or professional who wants to acquire, generate and communicate knowledge; abstracting is a core skill in the information literacy process and a prerequisite for lifelong learning in any field or discipline. Those who successfully learn and use it are equipped to penetrate document content, and to capture and represent the essence of information, its true substance and relevance. In sum, abstracting helps students become more self-sufficient and allows them to take greater control over the learning process. The abstract allows us to ascertain the interest a text might hold, and thus facilitates document selection. It is the information tool most highly demanded by scientists and professionals because it allows the original document to be consulted or rejected without accessing it directly [14].

The abstracting process fosters meaningful learning in that new concepts interact with already existing concepts in the abstractor's (student, graduate, professional) memory, to create extremely useful conceptual and semantic networks. The process performs an important function as a strategy for learning and representation by: 
- Identifying the text structure of the original document and its logical-conceptual articulation. Students should know what type of document they are dealing with and its schematic structure, as this will greatly facilitate subsequent selection, organisational and construction tasks.

- Selecting the relevant information; abstracting sharpens the ability to select and extract the relevant original information, since it activates a set of criteria that is dependent on the subject in question, but above all, on our learning objectives. Moreover, a greater need for selection arises when the target is to acquire meaningful learning from a specific corpus of information.

- Organising the information; it is not sufficient for the student to master the above analytical strategies (identifying the text structure and selecting the relevant information). They must be accompanied by skill in synthesising tasks, represented in two strategies: organisation and production of the resulting information. Before the information can be produced, it must first be organised. To this end, it must be given a structure that allows its component parts to be intentionally connected. Both the abstract and the results of the learning process should be structured, in other words, organised around a conceptual frame. Insufficiently clear organisation can lead to confusion and become, in consequence, an obstacle to learning.

- Creating new information, in the same way that the abstracting process results in information representative of the original document, when our target is to learn, it is advisable to express the results by producing the information learned. This production strategy is directly related to learning efficiency, as it helps to reinforce the result and guarantee the immediate incorporation of the information into our knowledge base. This process of production or construction, like that used in abstracting processes, may be either linear (text) or reticular (schemas, conceptual maps, etc.).

Given the importance of the abstract in higher education, the aim of this paper is to examine how it is produced, taught and learned from the perspective of information competencies and skills by analysing the procedures and stages involved in the abstract production process, specifying the competencies and skills necessary to carry it out, and putting forward proposals on how to improve these competencies and skills. One of our assumptions is that the abstracting process is structured in various stages and that if one of these is not performed correctly, it will have negative repercussions on the final product. For this reason, it is essential to scrutinise the competencies and skills involved in each stage in order to improve abstract quality.

\section{The abstracting problem}

In accordance with the dual function of the abstract/abstracting as a simplified representation of information and as a meaningful learning strategy, it is important to highlight its two sides: product and process, a source for learning and a methodology. In any approach to training students in acquiring specific competencies and skills, it is essential to acknowledge this dual nature: productive and procedural, documentary and learning-related.

The idea must be avoided that abstracting is a simple task that anyone can do with no previous training; abstracting requires knowledge of certain specific techniques and methodology and, without question, as Lancaster points out [15], a great deal of practice. In the scientific context, authors frequently write the abstracts 
for their own publications, even though, in general, they have not received any instruction or training in the task [16], which leads to poor quality abstracts. There is a general consensus on the stages to be followed when writing an abstract, although subtle differences among authors can be found in the scientific literature [17] [18] [19, 12] [20] [15] [21] [22].

Despite these slight discrepancies, abstracting is a single process that follows the stages outlined below.

\subsection{Reading and comprehension}

Reading is an intelligence-based process of visual perception that aims to decipher and comprehend the information contained in texts. Metacognitive research has demonstrated that the capacity to identify and remember the main ideas of a text is one of the bases for reading comprehension [23] [24], and one of the aspects that differentiates good from poor readers [25]. Reading can be regarded in three ways, depending on its target: for amusement, learning or selection of information. Abstractors should use the latter function in their work. The reading of a text enables the reader to identify the structure (heading, sub-heading, paragraphs, diagrams) and the content (main ideas, secondary ideas, conclusion) and to detect the author's intention and the subject the text deals with. It is important to read a text twice, the first time to get an initial feel for the text, and the second to examine its paragraphs more closely and analyse the ideas it contains. Having read the text, we can then attempt to understand its meaning.

\subsection{Analysis and interpretation}

Once the characteristics of the text to be abstracted, its typology and structure are known, the abstractor can begin the analysis. This stage involves breaking the text down into paragraphs in order to select the most relevant information through a segmented analysis of the whole [26]. In this way, the main ideas may be identified much more simply and precisely, and arranged according to their importance. Paragraphs fall into three types: explanatory (which open with sentences providing a general idea of what will be dealt with, and close with results or conclusions), descriptive (which expand on previously introduced ideas) and connective (which link paragraphs together and often give information about the previous and subsequent paragraphs). The interpretation of a text implies that the meaning abstractors attribute to it will be based on their own knowledge, since they relate their previous knowledge and conceptual structures to the information in the text in order to gain a clear idea of what the author is saying, how it is said and why [27].

\subsection{Synthesis}

Abstractors use their qualities, skills and knowledge to synthesise the content of the original document and condense it down to its most important points. To this end, the most important paragraphs or sentences must be identified -those that provide abundant and more relevant information- for subsequent work on the information. But abstractors also need to identify any redundant or extraneous information in order to exclude it, thereby recognising the information value of each paragraph and distinguishing essential from accessory paragraphs. Abstractors should use two complementary strategies in this process: selection, the positive extraction of what is essential and relevant, and omission, the negative elimination of what is irrelevant and unnecessary [28].

\subsection{Organisation and graphic representation of the information}

Once the main ideas have been synthesised, they must be organised and structured coherently, by relating concepts with each other for maximum comprehension. This can be done by arranging the information hierarchically to reveal how the main ideas of the text are articulated, by paying attention to the headings and subheadings, respecting the logical order of the text, using a numbering system to identify the ideas, and grouping related paragraphs together. In this way, abstractors can link the subject or the main concepts with the perspective 
the author uses to focus the text and his or her contributions. Some forms of graphic representation, such as conceptual maps or schemas, may be particularly effective, depending on the type of original information and the objectives of the abstract.

\subsection{Writing up}

The writing up of the abstract is particularly important, as this stage gives the whole process its definitive or final shape. It must assemble the essential information clearly and concisely, while remaining faithful to the original document and avoiding any personal input. It should be clearly understood that the abstract is not a commentary, a discussion or a summary. The abstract should be a short, grammatically complete text that includes the essential information from the original document in such a way that its content is meaningful and independent. Abstractors should remember that the intended readers of the abstract will not be familiar with the base text and therefore it must be written in precise, economic language that avoids repetitions and ambiguous constructions. The form in which the abstract is presented may vary from a single paragraph consisting of a sequence of organised, consistent sentences (recommended form) to structured abstracts that contain various paragraphs, each of which provides information on the methodology, results and conclusions of the original text.

While different text typologies require different abstracting methods and provide a wide range of products, abstracting involves a series of connected stages; any deficiencies in these stages will have repercussions on the final product. Students must therefore know how to carry out each stage correctly and acquire the specific skills they demand.

\section{Competencies and skills in the abstracting process}

The concept of competency is multidimensional and encompasses a combination of personal components (knowledge, cognitive skills, motivation, attitudes, and emotions), social components (context knowledge) and conducts (actions, behaviours, initiatives) to face complex demands in a particular context [29].

The concept of skill is the act or the quality of the person who uses it. Denecker [30] notes that this concept refers more to technical activities, or the manual skills involved in carrying out a job or an art. The concept of competency refers more closely to intellectual knowledge.

Some initial approaches to the competencies necessary for abstracting can be found in the ANECA "white book" on the Library Science and Documentation degree [31] and in the SEDIC (Spanish Society of Documentation and Scientific Information) translation of the "Euroguide LIS: the guide to competencies for European professionals in library and information services" [32]. These publications list the various competencies and skills required for the Library Science and Documentation degree, both at a generic level and in each of the subjects taught on the degree. Similarly, the "aprender a analizar, sintetizar, comunicar" (learning to analyse, synthesise and communicate) section of the Spanish ALFIN-EEES portal [33] specifies and gives examples of many of the competencies needed for abstracting. A thorough analysis of the specific competencies for abstracting can be found in "Aprendiendo a resumir: Prontuario y resolución de casos" [14] and recommends proficiency in the following skills:

- Mastery of the appropriate methods, techniques and strategies to identify and extract relevant information from the text

- Awareness of the various types of abstracts (objectives, function...)

- Knowledge of the specific terminology in the text

- Mastery of the analysis and synthesis techniques applied to any type of information (textual, visual, multimedia, etc.) 
- Awareness of the standards, instructions and recommendations for abstract writing.

- Skill in handling graphic tools to represent relevant information (conceptual maps, schemas, etc.)

- Skill in handling written communication techniques (text grammar, style etc.)

- Competency in evaluating, which enables the student to recognise the quality of a good abstract according to specified attributes [34]

- Skill in handling complementary documentation techniques (referencing/indexing and computer techniques) both for organising and storing abstracts in databases, and for recognising the potential and limitations of automating abstracts

However, these approaches are very generic and because they do not examine abstract production in depth, they fail to specify the competencies and skills required at each stage of the abstracting process.

The specific competencies required at each stage of the abstracting process are of a more practical nature, and are essentially learned through training. In this vein the paper "Measuring Students' Information Literacy Skills through Abstracting" [34], which examines the influence that training in specific cognitive and procedural competencies has on academic preparation in document abstracting may be consulted.

The remainder of the paper is devoted to the skills and competencies required for each of the five stages outlined above.

\subsection{Reading and comprehension: competencies and skills}

In addition to the basic linguistic knowledge needed to understand a text, whether in the reader's mother tongue or in a foreign language, principally English as the language with the greatest impact and diffusion, students must be able to read effectively and understand what they have read. They should be able to:

- Recognise the textual typology of the document. This is the first aspect to bear in mind when dealing with a text, since it is the initial information that will guide understanding. An essay, a scientific article, a patent or a newspaper article are all different from each other, they typically transmit different ideas, and do so in different ways.

- Understand what subject the text is concerned with. The student must be able to identify the subject of the text and be absolutely certain he or she has recognised it correctly. Depending on the nature of the text and the author's style, the main subject may not appear at the beginning of the text, but may follow anecdotal accounts or a secondary idea presented to set the context for the main subject.

- Identify the author's intention. The student must be able to understand the reason why the author has written the text and what he or she is trying to get across. The text typology can generally give an idea about this, but whether the author is expressing an opinion, recounting a fact, reviewing the literature or reporting a scientific finding should be distinguished.

- Understand the purpose of the text. Just as it is important to know what the author wants to transmit, the abstractor must be able to understand why the text has been written, what the value of the document is, to whom it is aimed and what it might contribute. 
Maria Pinto, Anne-Vinciane Doucet, Andrés Fernández-Ramos

- Understand the terminology. Students should be encouraged to increase their terminological resources; however, since it is impossible to be familiar with the terminology from all knowledge fields, they should at least know where to find information on a particular term or expression.

\subsection{Analysis and interpretation: competencies and skills}

A second, more in-depth reading of the text enables abstractors and learners at large to better understand and interpret the text by identifying its structure and sections. For this stage to be successful, the abstractor should:

- Understand the nature of the text and its characteristics. Each text typology has its own characteristics that the abstractor should be familiar with in order to acquire a thorough understanding and make an accurate interpretation. If an abstractor knows how a particular document type is articulated, he/she can identify its components more precisely and determine what they contribute to the whole.

- Recognise the text structure. Once the abstractor is aware of the text typology and its structures, he/she should be able to identify the structures in the text to be abstracted. This involves applying his/her theoretical knowledge of the text structures in different types of document. Obviously, a document can be structured in an enormous variety of ways, and these will not always correspond to a pattern, but it is clear that the more an abstractor knows about these structures at a theoretical level, the easier it should be to recognise them in practice.

- Recognise the units in the text. Texts are made up of smaller units of meaning: sections or chapters, paragraphs and sentences. Typography and punctuation can help to identify these units. Once they have been established, we can work with smaller, more manageable units of analysis in later stages (excluding superficial information, selecting the most important content etc.)

- Recognise the thread of the argument and the relationship among the text's units. The previously defined units of meaning fulfil a purpose within the text and are related to one another. It is essential to know how important these units of analysis are, and what function they perform, whether contextual, explanatory, methodological, conclusions, etc.

\subsection{Synthesis: competencies and skills}

In order to select the most important content of a document, the abstractor must be aware what information each section contributes and evaluate its importance in the document as a whole. Likewise, the abstractor should determine the information value of each paragraph by distinguishing whether they are explanatory, descriptive or connecting paragraphs.

- Distinguish what is pertinent and what is superficial. A text contains different types of information: explanatory, descriptive, connecting, examples, etc. Introductory paragraphs are generally used to place the text in context while examples are provided to help the reader's understanding. It is important to recognise the value of each paragraph or sentence within the text and thereby differentiate the superficial from the most important. 
- Identify the main subject or subjects. Although the text may deal with different issues, the abstractor should have sufficient abstracting capacity to represent the central issue through one or two concepts.

- Identify secondary subjects. Once the main subject has been determined, the abstractor should examine how it is supported by other ideas, arguments, explanations, etc., which shape the text and are also important to its comprehension.

\subsection{Organisation and representation of information: competencies and skills}

Having selected the most relevant information, the abstractor must organise and structure it by relating the ideas and concepts together. This requires knowledge of the different available techniques, which can be mastered through practical exercises. To carry out this stage, the abstractor should:

- Be familiar with the various ways information can be graphically represented. These may take the form of hierarchical schemas, conceptual maps, diagrams and so on. Each one has its own characteristics and problems and some are more suitable for particular information types than others. Familiarity with the various forms of graphic representation enables abstractors to choose the most appropriate form for the information they are dealing with.

- Establish relations between concepts and ideas. Because each type of graphic representation is based on the logical organisation of concepts, the abstractor must correctly identify the relationships between the concepts in order to represent them at a later stage.

- Be able to graphically represent and schematise the main ideas. Once the abstractor knows the different types of graphic representations and the relationships between the most important concepts, the information can be represented graphically.

\subsection{Writing up: competencies and skills}

The final stage in the abstracting process, once the ideas from the original text have been organised and structured, consists of the writing up of the abstract. The abstractor must know what type of abstract best fits the abstract contexts, and write it up accordingly. The abstractor should:

- Know the various types of abstracts. There is no single abstract type, just as they are not all written for a single purpose, nor in a single context. Although their typology is determined by various factors, the most important of these factors is content, according to which abstracts may be indicative, informative, analytical, structured, etc.

- Determine the appropriateness of each type of abstract for each type of text, project or context. The choice of abstract type will be determined by the type of information to be abstracted, and above all, by its context of production.

- Set out the ideas clearly and concisely. In writing up the abstract the abstractor must express as much of the important information as concisely as possible. 


\section{Development of infolit actions to provide skills in abstracting competency}

Twenty-five years of experience in the teaching of abstracting, together with feedback from the most qualified students enable us to recognise the need for classroom training in information literacy for document abstracting. These training programmes will improve the skills and abilities required for abstracting, a key competency for Aneca and other library associations. The proposal takes its inspiration from the educational portal alfineees; the subject gateway Ciberabstracts [35] which aims to improve the development of information skills; from international sources [21] [36] [37]; and from our own experience gained from research and international publications. The activities associated with each competency are presented below.

\subsection{Reading and comprehension}

When reading, it is essential to take a document reading approach, which entails concentrating without interruptions. Teachers should therefore take care to provide texts that are proportional in length to the available class time in order to avoid interruptions in the reading process. Before reading a text through from beginning to end, the abstractor/learner should know the type of text to be abstracted. A variety of exercises can help to develop this skill. Students may be given a range of texts taken from a variety of sources and asked to classify them (books, journal articles, grey literature, official texts, etc.). They then compare and identify the texts by date, language and type of publisher. Each student, or group of students, should come up with the categories. This exercise should be done regularly and the time it takes should be monitored and gradually reduced to increase speed, thus developing a sharper eye for the documents' external appearance. A variation on this exercise is to provide a table with the text types already given, which the students complete; in this case, they do not have to think up the categories themselves, but they must be familiar with them.

An exercise that develops the skill of general text structure detection, without reading the text, consists of focusing on the number of sections it has, whether or not it contains transition paragraphs, and whether we can deduce which paragraphs should be selected for reading. Once this skill has been acquired, lengthy articles cease to cause apprehension.

When the learner comes to reading the text, he/she can begin with exercises that give a general picture of the text through the headings and subheadings. If available, the author's abstract can be read, since it is not a document abstract; this will familiarise the learner with the subject presented by the author and allows him/her to check whether it corresponds with the titles.

Reading comprehension and the ability to detect author intention can be improved by organising students into groups to discuss texts. They are asked to: identify the main idea of the text and whether it corresponds with the title; give the text a title; and discuss the author's intention. These tasks enable the students to focus on selecting the main ideas and the way the abstract is written. Text comprehension may be checked by setting texts with comprehension questions to be debated in class.

Exercises to extract the subject concepts from the original documents are useful for identifying text subjects. The Lasswell [38] model can be used to this effect. The model asks five questions: who says what to whom, in which channel, and with what effect, thereby revealing the essential elements in the text and the main ideas. The SQ5R method (table 3) enables any text to be read effectively. Underlining is particularly useful in this first stage to highlight the sentences and paragraphs that best represent the main idea of the text.

\begin{tabular}{|l|l|}
\hline Survey $(\mathrm{S})$ & $\begin{array}{l}\text { Skim through the text content (headings and sub-headings, typology etc.). Carry out } \\
\text { a general inspection of the text to find out what it is about. }\end{array}$ \\
\hline Question $(\mathrm{Q})$ & Ask questions based on the headings and sub-headings. \\
\hline Read $(\mathrm{R})$ & Read the text and find the answers to the questions posed in the previous stage \\
\hline Recite $(\mathrm{R})$ & $\begin{array}{l}\text { Put the ideas the document contains into your own words, while at the same time } \\
\text { trying to remember the basic questions }\end{array}$ \\
\hline Review $(\mathrm{R})$ & Review the information to see whether you have retained the most important \\
\hline
\end{tabular}


Maria Pinto, Anne-Vinciane Doucet, Andrés Fernández-Ramos

\begin{tabular}{|l|l|}
\hline & aspects \\
\hline Record $(\mathrm{R})$ & Make a note of the most important ideas in the text. \\
\hline Reflect $(\mathrm{R})$ & Reflect on the material and make critical and evaluative judgements on it. \\
\hline
\end{tabular}

Table 3. SQ5R Method[39]

Understanding vocabulary is a further crucial element in reading comprehension. If students do not have a good command of the vocabulary, they will not understand the text and consequently will not abstract it appropriately. Students must therefore be familiar with the tools available to search for information on the terms and sentences they do not understand (dictionaries, encyclopaedias etc.). Groups may be formed to define vocabulary and agreement on the final definition can be reached in a class debate. Prior to abstracting, items of vocabulary can be chosen from the text for this exercise.

\subsection{Analysis and interpretation}

Training in the identification of text / document typologies and how to detect their structural components is essential in the analysis stage. Numbering the sections (headings) of the text and its units (paragraphs) is an efficient way to identify them and simplifies subsequent work .

Markers allow the structure of a text to be ascertained. It should be remembered that the analysis of how the ideas are formulated (vocabulary) and the organisation of these ideas (structure) underpin our search for important information. A student must be familiar with markers in order to define the structure. Students may be given an alphabetical list of markers and asked to arrange them in a previously designed table (for instance, according to whether they refer to the introduction, listing, contrast, restriction, cause, consequence, insistence, illustration or conclusion of ideas). The same marker may fall into various categories. An alternative exercise consists of reconstructing a text from a set of fragments, based on its logical structure and markers. This type of exercise also helps to improve writing skills. This stage is linked to the synthesis stage, which also makes use of markers.

\subsection{Synthesis}

The following procedures are recommended to carry out this task:

- PAY ATTENTION TO the paragraphs at the beginning and the end of the text, as this is usually where the main information is found.

- Exercises may consist of reading only the first and last paragraphs and summarising them. The rest of the text is then read, the ideas from the summary are compared with the main ideas taken from the other paragraphs, and any missing from the summary are noted. The important paragraphs are thus identified.

- IDENTIFY the main subject in each paragraph. This is done by asking what the paragraph discusses.

- FORMULATE specific questions on the text, such as what or whom the text discusses, which will help in understanding its content. This process is taken from the Lasswell model.

- $\quad$ LOOK FOR the most important key words in the text. This can also be conducted using the questions from the Lasswell model.

- VISUALISE the inserts, schemas, figures, illustrations.

- $\quad$ NOTE the type of lettering used (italics, bold, insets) as this may give an indication of the importance of these words. 
To detect the main ideas and the important key words, students are given articles with certain words in bold or in brackets. They are then asked to explain why these forms are used (for instance, key words may be in bold and examples in brackets).

The main ideas can be distinguished from secondary ideas or examples by an exercise done prior to abstracting. A table is given out containing two columns: one with the main ideas noted by the lecturer, and the other with the details or examples. The students are asked to provide examples or details for each main idea, based on the text that they have not yet read. This is followed by a class debate on the examples provided by each student. A variation on this exercise is to ask the students to find both the main ideas and the examples from the text.

This task becomes easier once the markers have been learnt (linking words, signalling, expressions, images, etc).

\subsection{Organising and representing the information}

Two types of representation are particularly useful in abstracting: schemas and conceptual maps. The former are usually hierarchical and reflect the structure of the base text by arranging the ideas from the most general to the most specific. Training in this skill involves practice in ordering ideas logically and hierarchically (sequence construction), in choosing the visual identification symbols for each level of the schema and in selecting the type of schema (keys, bars etc.,) to separate each level.

On the other hand, conceptual maps [40] involve a much more visual representation of the information based on the relation between key concepts. Basic guidelines should be followed when learning how to create conceptual maps: select the concepts, list the concepts from the most abstract to the most concrete, group together related concepts and incorporate other concepts of interest, order them in a two- or three-dimensional frame, link each pair of concepts with propositionally labelled lines. Students should also be familiar with and able to use the various specific software packages available for this process. They can be trained in organising concepts by grouping together concepts on a particular subject from a list the lecturer gives them. Linking skills can be honed by giving students a series of linked concepts with linking and labelling errors to correct.

To help students learn to organise concepts, in a conceptual map or otherwise, they can be asked to organise the information by filling in a table of subjects that appear in the article. Different types of tables can be used: organisation according to differences and similarities, according to clusters, according to a cycle, or by main and secondary ideas. This helps students to see the range of ways in which information can be represented.

A different type of exercise is to use the text itself to carry out two types of representation, a schema of the text and a conceptual map. These exercises allow the key concepts to be extracted.

\subsection{Writing up}

When training students to write up the various types of abstract, it should be remembered that some types are more concise than others and the synthesising stage will therefore be greater in some cases than in others. It is advisable to start with longer abstracts and then use them to create shorter versions (indicative, telegraphic). In the case of structured abstracts, the selected information should be adapted to a concrete schema.

Because an abstract is a new document, and not simply an extraction of ideas, the student must be able to write correctly, clearly and concisely. Writing skills can be greatly improved by reading other abstracts, studying writing techniques, being aware of style rules and above all, with plenty of practice.

Writing an abstract means reformulating, by rewording what is written in the text. This process can be improved through exercises in searching for synonyms to extend the students' vocabulary or by exercises where affirmative statements are replaced by negative ones, and vice versa.

Students can be given over-long abstracts to shorten, and asked to justify their editing decisions. They can also be asked to correct incorrect or ambiguous sentences, and at a later stage, they may be shown various 
Maria Pinto, Anne-Vinciane Doucet, Andrés Fernández-Ramos

abstracts of the same text and asked to identify mistakes in writing or structure. If the logical structure is not easily understood, it can be improved using an exercise in which a text without markers is given out for the students to complete.

Exercises can also combine a selection of the competencies with the final writing up stage. They may be given a text with questions about certain paragraphs. Students might be asked to identify the markers, reformulate certain expressions, write a paragraph in question form, highlight the logic that may appear between two paragraphs, and so on, before writing up the complete abstract. This will reveal the "difficult" points in the text prior to the writing up stage.

The following table (table 4) summarize the main infolit actions:

\begin{tabular}{|c|c|c|}
\hline STAGES & COMPETENCIES AND SKILLS & Training actions/exercises \\
\hline \multirow[t]{5}{*}{$\begin{array}{l}\text { Reading } \\
\text { comprehension }\end{array}$} & Recognition of the document text typology & $\begin{array}{l}\text { Present various text types for } \\
\text { classification }\end{array}$ \\
\hline & $\begin{array}{l}\text { Understanding which subject the text deals } \\
\text { with. }\end{array}$ & $\begin{array}{l}\text { Organise debates based on the } \\
\text { Lasswell method questions }\end{array}$ \\
\hline & Identifying the author's intention & Organise debates \\
\hline & Understanding the purpose of the text & Organise debates \\
\hline & Understanding the terminology used. & $\begin{array}{lrr}\text { Timed dictionary } & \text { and } \\
\text { encyclopaedia searches } & \text { for } \\
\text { specific terms } & & \end{array}$ \\
\hline \multirow[t]{4}{*}{$\begin{array}{l}\text { Analysis and } \\
\text { interpretation }\end{array}$} & $\begin{array}{l}\text { Understanding the nature of the text and its } \\
\text { features }\end{array}$ & Identification of different text types \\
\hline & Recognising the text structure & $\begin{array}{l}\text { Organise markers, analyse } \\
\text { sections or headings }\end{array}$ \\
\hline & $\begin{array}{l}\text { Recognise the text sections and the units } \\
\text { they are comprised of }\end{array}$ & Examine the typography \\
\hline & $\begin{array}{l}\text { Recognise the thread of the argument and } \\
\text { the relation between the text's component } \\
\text { units }\end{array}$ & $\begin{array}{l}\text { Practice in sequencing the } \\
\text { concepts, headings and sections of } \\
\text { a text }\end{array}$ \\
\hline \multirow[t]{3}{*}{ Synthesis } & $\begin{array}{l}\text { Distinguish what is important from the } \\
\text { superficial information in a text }\end{array}$ & $\begin{array}{l}\text { Use the Lasswell model } \\
\text { Use tables to visualise information }\end{array}$ \\
\hline & Identify the main subject(s) & $\begin{array}{l}\text { Prompts in the text to recognise } \\
\text { the importance of what is } \\
\text { highlighted }\end{array}$ \\
\hline & Identify the secondary subjects & $\begin{array}{l}\text { Prompts in the text to recognise } \\
\text { the importance of what is } \\
\text { highlighted }\end{array}$ \\
\hline \multirow{2}{*}{$\begin{array}{l}\text { Organisation and } \\
\text { representation of the } \\
\text { information }\end{array}$} & $\begin{array}{l}\text { Know the different ways of representing } \\
\text { information graphically }\end{array}$ & $\begin{array}{l}\text { Discuss the types of graphic } \\
\text { representation }\end{array}$ \\
\hline & $\begin{array}{l}\text { Establish relationships between concepts } \\
\text { and ideas }\end{array}$ & $\begin{array}{l}\text { Use schemas of the ideas and } \\
\text { relate them to each other }\end{array}$ \\
\hline
\end{tabular}


Maria Pinto, Anne-Vinciane Doucet, Andrés Fernández-Ramos

\begin{tabular}{|l|l|l|}
\hline \multirow{3}{*}{ Writing up } & $\begin{array}{l}\text { Be able to graphically represent and } \\
\text { schematise the main ideas }\end{array}$ & $\begin{array}{l}\text { Practice with different groups of } \\
\text { concepts }\end{array}$ \\
\hline & $\begin{array}{l}\text { Be able to express ideas clearly and } \\
\text { concisely }\end{array}$ & $\begin{array}{l}\text { Shorten texts and correct } \\
\text { ambiguities }\end{array}$ \\
\cline { 2 - 3 } & $\begin{array}{l}\text { Be able to decide on the suitability of each with the range of abstract types } \\
\text { abstract type for each type of text, project or } \\
\text { context }\end{array}$ & $\begin{array}{l}\text { Classify acenare of the different abstract } \\
\text { types and match them to different } \\
\text { text types }\end{array}$ \\
\hline
\end{tabular}

Table 4. Relationship between the abstracting stages and competencies and skills.

\section{Conclusions}

Abstracting and synthesising abilities are clearly increasing in importance as a consequence of the enormous amount of information available today, predominantly due to the huge use of information technologies and particularly the Internet. Therefore, abstracting is considered to be one of the basic competencies according to the standard Information Literacy principles. Yet abstracting is a complex process that must be learned and practiced if it is to be done proficiently. At the same time, an effective learning process requires a series of cognitive, documentary, technological and communicative competencies and skills, some of a general nature, and others more specific. An in-depth analysis of the various stages in the abstracting process in order to approach the issue of how it might be learned in a structured way is proposed. The relationship between these stages is then demonstrated and a series of specific competencies necessary to put these stages into practice is detailed. By identifying these competencies in a structured manner, a better understanding is gained of the factors that influence and determine the abstractor's capacity to create an abstract.

By identifying these skills and competencies, it is easier to guide the learning process, since the student or abstractor is frequently assumed to be ready to take on the task of abstracting, and the fact that some aspects of their training may need consolidating is often ignored.

A detailed evaluative analysis of the stages the students or abstractors follow will reveal exactly which stage or link is causing them the greatest problems, and enable teachers to improve their training by strengthening the competencies and skills related to that stage. This procedure is a notable improvement on any evaluation that focuses solely on the final product, the abstract, and does not provide any information on where the root of the problem lies or where greater emphasis should be placed.

Standard templates [34] in which the student specifies the stages he or she has carried out to produce the abstract can be effective diagnostic tools. These templates provide information on the stages that cause students the greatest difficulties and consequently, which skills and competencies require further reinforcement as part of their training.

The paper puts forward a series of guidelines and recommendations to improve students' competencies in abstracting, and specifies how to improve each of the competencies and skills linked to each of the stages in the abstracting process. In the near future, we hope to use this work as the basis on which to develop an interactive web-based tutorial, to improve abstracting competencies through exercises, self-administered tests and solving practical cases in each of the skills involved in abstract production. 


\section{References}

[1] C. Mouraby, Apprendre à transmettre: un nouvel élément de l'identité du bibliothécaire, $B B F$ 50(6) (2005) 80-89.

[2] C.S. Bruce, Information literacy as a catalyst for educational change: a background paper. White Paper prepared for UNESCO, the U.S. National Commission on Libraries and Information Science, and the National Forum on Information Literacy, for use at the Information Literacy Meeting of Experts, Prague, The Czech Republic (2002). Availbale at http://www.nclis.gov/libinter/infolitconf\&meet/papers/brucefullpaper.pdf (accessed 16 October 2007).

[3] S. Andretta, Information literacy: a practitioner's guide (Changos, Oxford, 2005).

[4] J. Elmborg, Critical information literacy: implications for instructional practice, Journal of Academic librarianship 32(2) (2006) 192-199.

[5] A. Lloyd, Information literacy landscapes: an emerging picture, Journal of Documentation 62(5) (2006) 570-583.

[6] C. Gibson (ed.), Student engagement and information literacy (Association of College and Research Libraries, American Library Association, Chicago, 2006).

[7] S. Webber and B. Johnston, Information Literacy: Definitions and models (2003). Available at http://dis.shef.ac.uk/literacy/definitions.htm (accessed 16 October 2007).

[8] Association of College and Research Libraries, Information Literacy Competency Standards for Higher Education (ACRL, Chicago, 2000). Available at http://www.ala.org/ala/acrl/acrlstandards/standards.pdf (accessed 16 October 2007).

[9] American Association of School Librarians and Association for Educational Communications and Technology, Information literacy standards for student learning: standards and indicators (1996). Available at http://slisweb.sjsu.edu/courses/250.loertscher/modelaasl.html (accessed 16 October 2007).

[10] SCONUL, Information skills in higher education: a SCONUL position paper (Society of College, National and University Libraries, London, 1999). Available at:

http://www.sconul.ac.uk/groups/information_literacy/papers/Seven_pillars2.pdf (accessed 16 October 2007).

[11] A. Bundy (ed), Australian and New Zealand Information Literacy Framework: Principles, Standards and Practice, 2 ed. (Australian and New Zealand Institute for Information Literacy, Adelaide, 2004). Available at http://www.caul.edu.au/info-literacy/InfoLiteracyFramework.pdf (accessed 16 October 2007).

[12] M. Pinto, El resumen documental: Paradigmas, modelos y método (Fundación Germán Sánchez Ruipérez, Madrid, 2001).

[13] J. Hartley and M. Benjamin, An evaluation of structured abstracts in journals published by the British Psychological Society, British Journal of Educational Psychology 68 (1998) 443-456.

[14] M. Pinto, M. Mitre, A.V. Doucet and M.J. Sanchez, Aprendiendo a resumir: prontuario y resolución de casos (Trea, Gijón, 2005).

[15] F.W. Lancaster, Indexing and abstracting in theory and practice (Factet Publishing, London, 2003).

[16] H. Borko and M. Bernier, Abstracting concepts and methods (Academic Press, New York, 1975).

[17] E.T. Cremmins, The art of abstracting (ISI Press, Philadelphia, 1982).

[18] J. Hutchins, Summarization: some problems and methods. Informatics 9, Meaning: the frontier of informatics, Aslib (1997) 151-173.

[19] M. Pinto, Documentary abstracting: toward a methodological model, Journal of the American Society for Information Science 46(3) (1995) 225-234. 
Maria Pinto, Anne-Vinciane Doucet, Andrés Fernández-Ramos

[20] I. Monday, Les processus cognitifs et la rédaction de résumés, Documentation et Bibliotheques (1996) 5563.

[21] S. Waller, L'analyse documentaire: une approche méthodologique (ADBS, Paris, 1999).

[22] D.B. Cleveland and A.D. Cleveland, Introduction to indexing and abstracting (Libraries Unlimiteg, Englewood, CO, 1990).

[23] M.W. Aulls, Development and remedial reading in the middle grades (Allyn \& Bacon, Boston, 1978).

[24] A.J. Harris and E.R. Sipa, How to increase reading ability: a guide to developmental and remedial methods (Longman, New York, 1980).

[25] P.N. Winograd, Strategic difficulties in summarizing texts, Reading research quarterly 19 (1984) 404-425.

[26] R. Petitjean, La transformation de texte (Cedic, Paris, 1984).

[27] W. Kintsch and T.A. Van Dijk, Toward a Model of Text Comprehension and Production, Psychological Review, 85(5) (1978) 363-394.

[28] D. Armogathe, La synthèse de documents (Bordas, Paris, 1998).

[29] OECD, The definition and selection of key competencies. Executive Summary (2005). Available at https://www.pisa.oecd.org/dataoecd/47/61/35070367.pdf (accessed 16 October 2007).

[30] C. Denecker, Les compétences documentaires: des processus mentaux à l'utilisation de l'information (Presses de l'ENSSIB, Villeurbanne, 2003).

[31] Agencia nacional de evaluación de la calidad y acreditación, Libro blanco: Título de grado en Información y Documentación (ANECA, Madrid, 2004). Available at: http://www.aneca.es/activin/docs/libroblanco_jun05_documentacion.pdf (accessed 16 October 2007).

[32] Relación de eurocompetencias en información y documentación (SEDIC, Madrid, 2000).

[33] M. Pinto Portal Alfin-EEES (2006). Available at: http://www.mariapinto.es/alfineees (accessed 16 October 2007).

[34] M. Pinto, A. Fernández-Ramos and A.V. Doucet, Measuring Students’ Information Literacy Skills through Abstracting, College and Research Libraries (In press).

[35] M. Pinto, Cyberabstracts: a portal on the subject of abstracting designed to improve information literacy skills, Journal of Information Science (In press).

[36] G. Cotentin-Rey, Le résumé (Editions clé International, Paris, 1992).

[37] N. Wormeli, Summarization in any subject: 50 techniques to improve student learning (Association for supervision and curriculum development, Alexandria, VA, USA, 2004).

[38] H. D. Lasswell, Estructura y función de la comunicación en la sociedad. In: M. de Moragas (ed.), Sociología de la comunicación de masas, II, estructura, funciones y efectos (Gustavo Pili, Barcelona, 1985).

[39] E.L. Thomas and H.A. Robinson, Duplicator master for improving reading in every class (Allyn \& Bacon, Boston, 1979).

[40] J.D. Novack, Learning, Creating, and Using Knowledge: Concept maps as facilitative tools for schools and corporations (Lawrence Erlbaum \& Assoc., Mahwah, N.J., 1998). 